\title{
Proclus' Doctrine of Participation in Maximus the Confessor's Centuries of Theology I.48-50
}

\author{
Jonathan Greig (Ludwig-Maximilians-Universität), Munich, Germany \\ Delivered for the Oxford Patristics Conference, August 13, 2015 \\ Revised draft for forthcoming article in Studia Patristica, 2017
}

\section{Introduction}

There has been a fair consensus that St. Maximus the Confessor is greatly influenced by Neoplatonism, in good part thanks to his appropriation of Pseudo-Dionysius' thought. ${ }^{1}$ A particular group of passages stand out in this regard in the Centuries of Theology ${ }^{2} 1.48-50$ (PG:90, 1100C-1101B), where Maximus employs a framework of participation between God and God's eternal and temporal works. ${ }^{3}$ In explaining how God can continuing working when in the Genesis account God is said to have 'rested' from his work, Maximus distinguishes between God's eternal works, which are participated, from God's temporal works, which participate in the latter. Maximus' formulation has striking parallels to Proclus' structure of participation involving three terms for any given order of reality: the unparticipated, participated, and the participant.

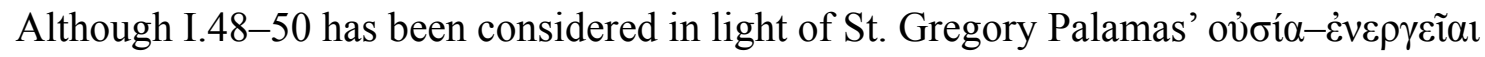
distinction in God, ${ }^{4}$ no analysis has been made on the influence and reception of Proclus. In this paper I wish to make a close comparison of Maximus and Proclus with their metaphysics of participation, beginning with an analysis of the Centuries passage followed by an overview and comparison with Proclus' general framework of participation. I propose that Maximus makes certain, essential changes from Proclus' structure, one of which is the

\footnotetext{
${ }^{1}$ See, for instance, Carlos Steel, 'Maximus Confessor on Theory and Praxis. A Commentary on Ambigua Ad Johannem Vi (10) 1-19' in Thomas Bénatouïl, Mauro Bonazzi (eds), Theoria, Praxis, and the Contemplative Life After Plato and Aristotle (Leiden: 2012) and Stephen Gersh, From Iamblichus to Eriugena: An Investigation of the Prehistory and Evolution of the Pseudo-Dionysian Tradition (Leiden: 1978).

${ }^{2}$ Here onward abbreviated ' $C T$ '.

${ }^{3}$ Prior studies of these passages (that I am currently aware of) are John Demetracopoulos, 'Palamas Transformed: Palamite Interpretations of the Distinction Between God's "Essence" and "Energies" in Late Byzantium', Bibliotheca 11 (2011) 279, n. 46; David Bradshaw, Aristotle East and West (Cambridge, 2004) 189-90; and David Bradshaw, 'Maximus the Confessor' in Lloyd Gerson (ed.), The Cambridge History of Philosophy in Late Antiquity (Cambridge, 2012), 816-7. While Proclus is briefly mentioned in these, no direct comparison is made between Maximus and Proclus.

${ }^{4}$ See, for instance, Demetracopoulos (2011) 279-80, where he notes Palamas' use 'ả

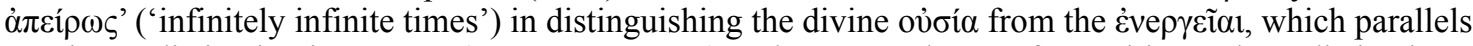
Maximus' distinction in CT I.49 (see p. 4, esp. n. 9). Palamas was known for positing a sharp distinction

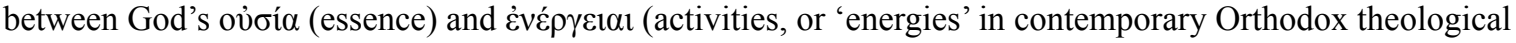
literature), with the former as completely unknowable and the latter as knowable and participated by creatures,

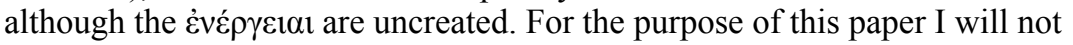


allowance of multiple participants to share in one, same participated entity, unlike Proclus. Another, more significant change is the denial of self-subsistence to Maximus' participated entities, unlike Proclus' participated entities, like the henads, which are separate deities in relation to the Neoplatonic first principle, the One. This shift would potentially mark an antipolytheistic move by Maximus, where the participated 'works' become aspects of God, although Maximus appears to maintain an ontological distinction between God in himself and the participated 'works' or entities. The outcome is that Maximus has inherited Proclus' structure for participation, while affirming an essential relation between the unparticipated and participated in a stronger sense than one finds in Proclus.

\section{Maximus' Framework of Participation in CT I.48-50}

CT I.48-50 forms a particular group within the whole work which is concerned with establishing what constitutes being a work of God, what kinds of those works exist, and in what sense God is related to those works. I.48 introduces two particular kinds of works that belong to God:

For the worthy it should be sought out how certain things are fit to be understood as works which God began in creation, and again certain things which God did not begin. For if he rested from all works which he began to produce, it is clear he did not rest from those which he did not begin to produce. At no time then: the works of God, on the one hand, which began to be in time are all participating beings, just as the different essences of beings. For they have non-being prior to their own being; God was at some point, when beings which participate were not. But the works of God which did not happen to begin to be in time are participated beings, which participating beings partake according to grace: just as with goodness, and everything of goodness if it is embraced in account. And simply all life, immortality, simplicity, immutability, and infinity; such things are contemplated in an essential way around him. Those are also works of God, and they did not begin in time. $(1100 \mathrm{C}-\mathrm{D})^{5}$

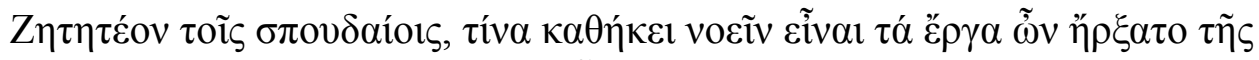

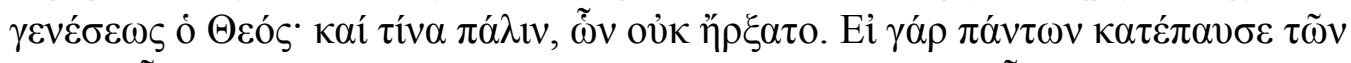

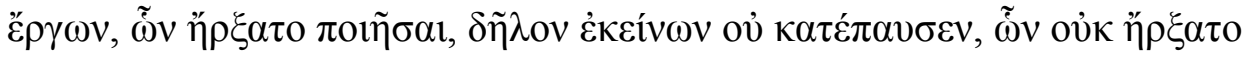

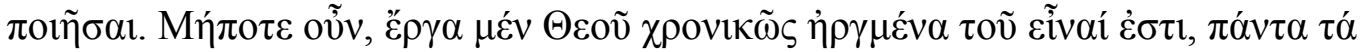

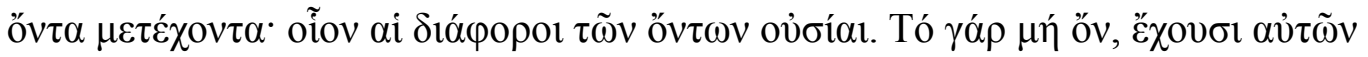

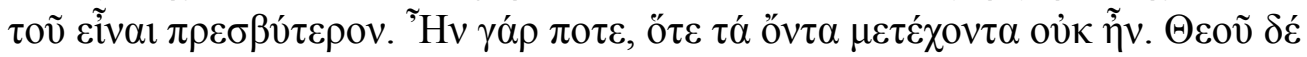

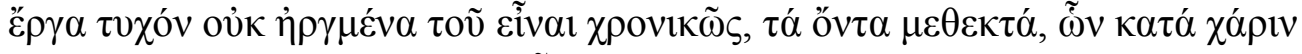

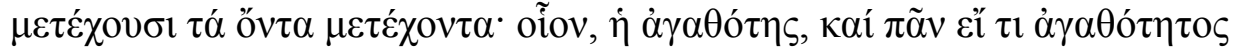

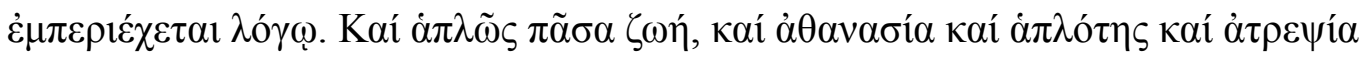

\footnotetext{
${ }^{5}$ All translations are my own unless otherwise noted.
} 


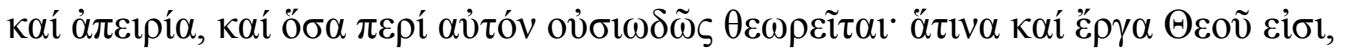

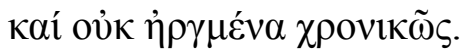

In beginning this passage Maximus sets out a distinction between the works God 'rested' from in relation to those which does not cease from doing. The allusion of God's 'rest' hearkens back to Genesis 2:2 from the Old Testament, where God rests from his work at the end of creation on the seventh day. An implicit concern one might have is how God continues working in spite his having rested at the end of creation. Given this, Maximus gives two kinds of 'works': those which have a created beginning in time and those which do not have a beginning ( $\alpha v \alpha \rho \chi \circ \varsigma)$ by nature- the former and latter each corresponding to works which God did finish, and from which God does not rest. Noteworthy is Maximus' statement that

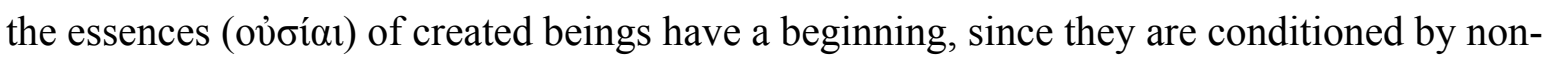
being ( $\tau$ ó $\mu \eta ́$ őv) as their origin. This is in contrast to the other kinds of divine works which are marked out as eternal and outside time. The latter case suggests generic perfections, as with the given examples of goodness, life, immortality, and so on, while the former implies created beings - like trees, animals, plants, and so on, although Maximus does not specify these. Since even the essences of the created works are time-bound, this would likely rule out a Platonist position that the essences of generated material particulars are eternal in relation to their generated, physical images. On the other hand, the maintenance of properties like 'goodness', 6 'infinity', 'life' and so on as eternal 'works' suggests such a Platonic-style interpretation. Maximus' reasoning appears to be that, if the properties are perfections which, by their nature, do not imply time or beginning in their definitions, they must exist as separate instantiations before created beings are generated.

The division between created works and uncreated works leads to Maximus' construal of the former set as participated beings ( $\mu \varepsilon \theta \varepsilon \kappa \tau \alpha$ ), and the latter set as participants ( $\mu \varepsilon \tau \varepsilon \chi o ́ v \tau \alpha)$, of the former. Thus, a participant is not said to be 'good', 'living', or even have 'being' in virtue of itself, but in virtue of its participation in the corresponding work. The later CT I.50 makes this clear:

Those [entities] which began in time are, and are said to be this, by participation of those things which did not begin in time, wherefore they both are and are said

\footnotetext{
${ }^{6}$ One should also note Maximus' prioritization of 'goodness' ( $\dot{\eta} \alpha \gamma \alpha \theta$ ó $\left.\left.\tau\right\rceil\right)$ ) over the other attributes in I.48. This reflects a common Neoplatonic theme of the Good's priority over all other attributes. See for instance Proclus, Elements of Theology, Prop. 8 (Dodds 8.29-30): 'All that in any way participates the Good is subordinate to the

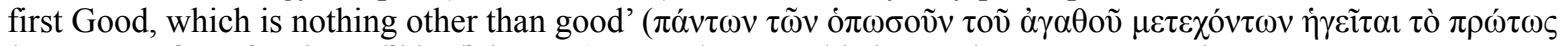

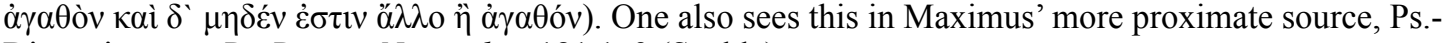
Dionysius, e.g. De Divinis Nominibus 181.1-3 (Suchla).
} 
to be. For all living things and immortal things, both holy and virtuous things, God is the craftsman: for he transcends the essence of all that can be understood and spoken. (1101B)

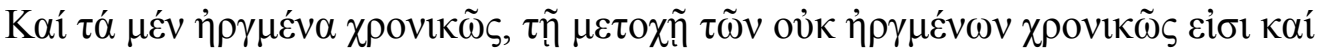

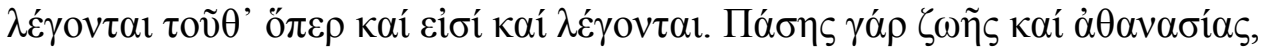

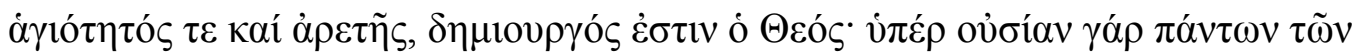

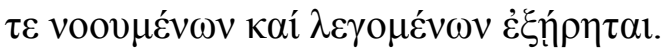

Maximus' qualification of what can be 'spoken' or said 'to be' by implication refers to the participated and participating works. This would confirm God's transcendence beyond positive attributions, since the latter refer to either participants or the participated works, while God's transcendence reflects his priority to the works as the creator or

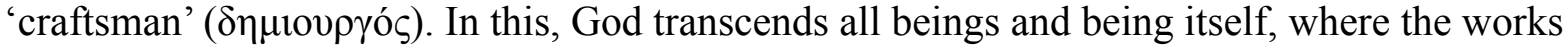
have the account of being predicated of them. ${ }^{7}$ In this sense God would not be participated, in contrast to the eternal works which are.

Earlier in I.48, the participated works, such as 'goodness', 'infinity', and so on are said to be contemplated 'in an essential way' about God ( $\pi \varepsilon \rho i ́ \alpha$ sense this is paradoxical with I.50 above, since God is supposed to transcend the essence all beings 'that can be understood and spoken'. This would appear to suggest that any essential relation, or let alone any relation, between God and the participated works should not be perceived. To move beyond this initial impasse, one should consider two ways of ' $\pi \varepsilon \rho i$ ' in

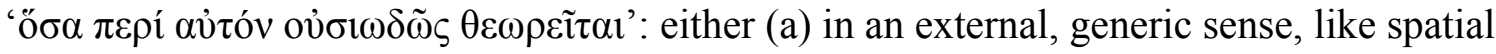
positioning (e.g. the moon as 'around' the earth, although not numerically identical with the earth), or (b) in the sense of an essential property (e.g. speaking of rationality 'concerning' or 'in relation to' man; 'rationality' and 'man' would therefore be numerically identical). (B) appears to be suggested with the language of the attributes as contemplated 'essentially about

\footnotetext{
${ }^{7}$ See Maximus, CT I.49, 1101A; quoted on p. 6, n. 13.

8 The phrase $\pi \varepsilon \rho$ í $\alpha$ $\tau$ óv in relation to God recurs in earlier Fathers, for instance Gregory of Nyssa, Against Eunomius 2.89, 102, 582, etc. Cf. D. Bradshaw, 'Maximus the Confessor' (2010), 817.
} 


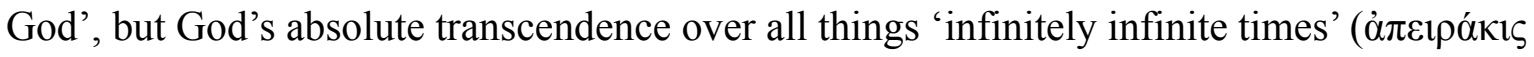
$\dot{\alpha} \pi \varepsilon i ́ p \omega \varsigma)(\mathrm{I} .49,1101 \mathrm{~A})^{9}$ implies the former sense of spatial, or ontological, positioning.

Unfortunately Maximus does not give an explicit indication either way in these passages, but two things could be said about the status of these participated works: (1) their numerical

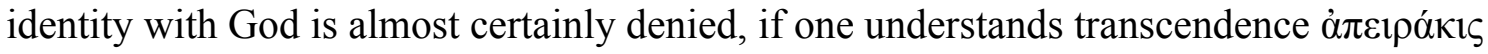
$\dot{\alpha} \pi \varepsilon i ́ \rho \omega \varsigma$ to negate any essential predication or numerical identity; but (2) the participated works and God both exist prior to time and generated beings, which implies some kind of essential relation, if not an essential predication. (2) is brought out at the end of I.48, where Maximus says that the participated works 'have God most solely as the eternal generator of

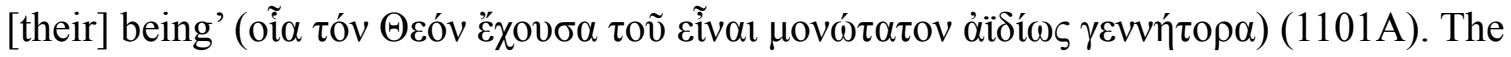
emphasis on God as the sole source of the works suggests not only that they have no other external cause than God, but even that they could not have their source in themselves as, for instance, being self-caused. ${ }^{10}$ This would suggest that the works must have an essential relation to God as their cause, but while still denying numerical identity, as in (1). An analogy to this would be essential accidents: although risibility is not included in the account of rationality, it follows as a necessary accident on whatever possesses rationality, such as man. ${ }^{11}$ While in examples like this numerical identity entails, unlike (1), the analogy holds insofar as essential accidents follow on their corresponding essences without entailing identity in their accounts. This would appear to be the sense Maximus has in mind for the participated works as 'contemplated essentially' in relation to God. Thus, a created being partaking in an eternally-generated work like 'life' or 'simplicity' shares in some sense in God, or in a divine attribute, but in a way that denies numerical identity. One can see this

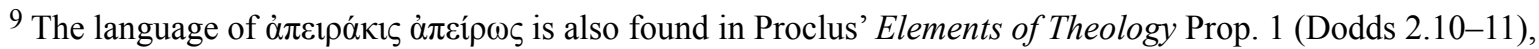
but strikingly in a purely negative sense, where Proclus states that nothing can be made up 'from infinitely

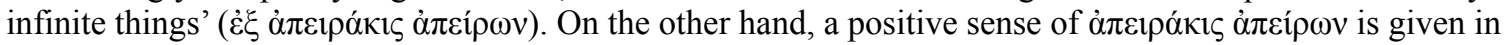
Damascius, De Principiis I, 106.17-19 (Ruelle), where the Many-One, or Unlimited-itself, is defined as such (special thanks to Antonio Vargas for initially pointing this out). In this respect Maximus could be influenced by Damascius.
}

See also Maximus, Centuries of Theology I.1-2, 4, where God is described as, among other negative attributes, beyond 'essence, power, and act'. This corresponds to a general Neoplatonic description of the One as beyond the same triad of essence, power, and act (see e.g. Proclus, Commentary on Parmenides 1070.15-1071.3 (Cousin)). This is further proof that Maximus is working closely within a Neoplatonic framework for discussing God's transcendence and causal relation.

10 Something that Proclus otherwise strongly establishes for the henads and other participated entities, like intellects and souls, in general. Discussed in the following section, below. I give further evidence below, from CT I.47, why self-causation seems to be implicitly denied for the eternal, participated works.

${ }^{11}$ See Aristotle, Posterior Analytics I.4, esp. 73b10-15, for the sense of properties that belong in themselves ( $\kappa \theta^{\prime}$ ' i $\tau$ ó) to something else, like 'death' with a sacrifice (although definitionally distinct), contrasted with properties that belong to something else accidentally ( $\delta$ ’’ $\alpha$ ìò $\sigma v \mu \beta \varepsilon \beta \eta \kappa o ́ s)$. 
brought out in CT I.54 when Maximus speaks of 'being' and 'life' as properly belonging to God, where in partaking of these properties one 'becomes god by deification' (oĩ $\alpha \alpha i ̀$ $\alpha$ ì̀

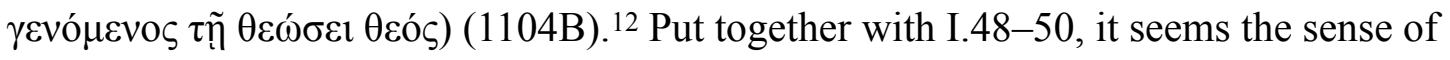
'becoming god' is dependent on the participated works and their analogous function to essential accidents. In the end this affirms the participated works' status as intermediaries between God and created beings, since they facilitate a medium in communicating effects from God while affirming the ontological divide between the two. As we will see in the next section, this parallels Proclus' understanding of participated entities as a bridge between the unparticipated and the participants.

One lingering question remains with the participated works in terms of their mode of existence in relation to the participants. In CT I.49, Maximus states that the participated works are immanent, having been 'implanted for created beings according to grace, as much

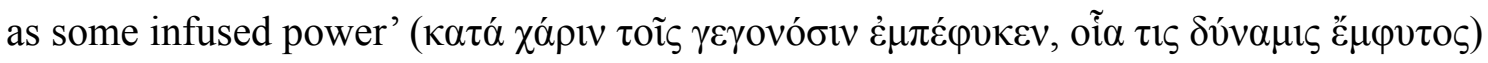
(1101A). ${ }^{13}$ This would contrast with I.48's emphasis on the participated works' pre-existence to created beings, where if the participated works were just immanent powers, they would depend on the participants for their existence. A closer consideration of the passage's context should bring out an implicit answer: at the beginning it establishes God as transcending both the participated works and the participants, while at the end the timeless works' immanence

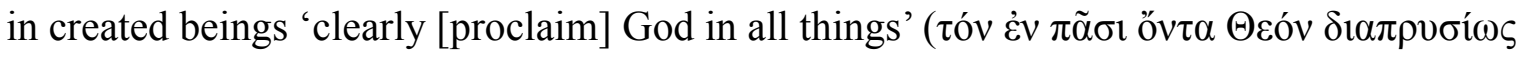

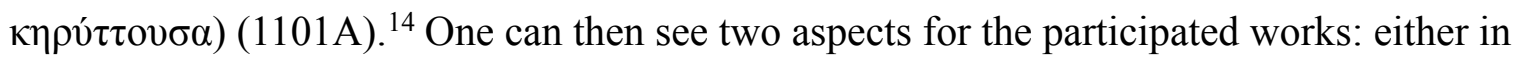
their association with God as transcendent, and therefore belonging 'solely' to God, or in their relation to created beings as immanent powers. Created beings which have the

\footnotetext{
${ }^{12}$ CT I.54 (1104B): '...[such a man] lives the blessed life of God, who alone is said to be and is in very truth the

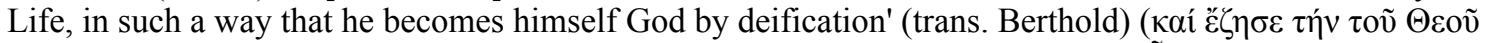

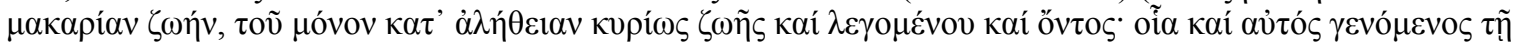
$\theta \varepsilon \dot{\sigma \varepsilon l} \theta \varepsilon$ cós.). See also CTD II.88 (1168A): ‘ ... [the soul] becomes God through participation in divine grace by itself ceasing from ail activities of mind and sense and with them the natural activities of the body which become Godlike along with it in a participation of deification proper to it' (trans. Berthold) (

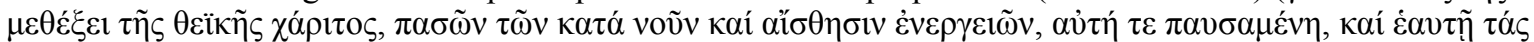

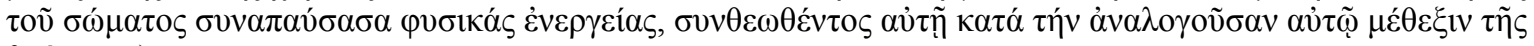

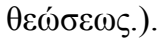

${ }^{13}$ CT I.49 (1101A): 'For if everything has the account of being predicated, it happens to be a work of God: on the one hand, even it has had its beginning of being according to generation by time; and also it has been

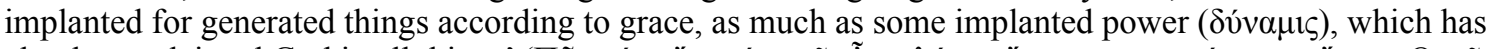

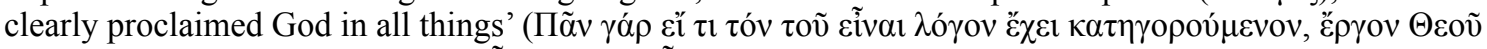

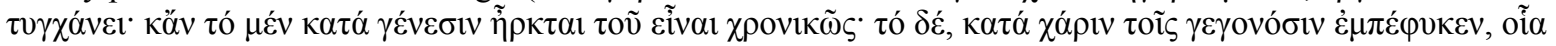

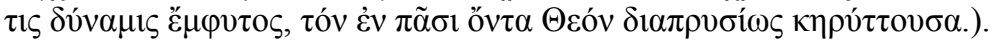

14 See also, e.g., Maximus, Centuries of Theology I.82, which further develops how and why God transcends 'all that can be understood and spoken'; cf. I.83, II.2 (1125C); II.3.
} 
properties of 'goodness' and 'being', for instance, then possess these as received 'powers' caused by the participated works in their timeless, pre-existing aspect.

We can conclude that, just as the participated works are intermediaries between God and created beings, from I.48 and the beginning of I.49, so also the 'powers' generated in created beings are a bridge between the eternally-existing participated works and time-bound, created beings. The overall structure of participation can be summarized as: (1) God in himself,

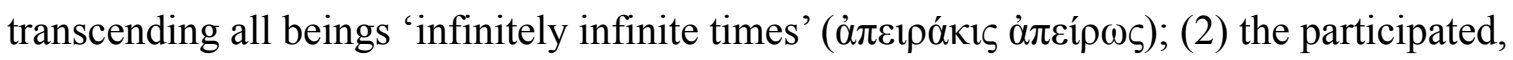
eternal works of God pre-existing created beings; $\left(2^{*}\right)$ the generated powers of the participated works in creatures; and (3) creatures, as participants of (2), having their being and essence in time. One can see that a picture of continuity emerges from God to creatures in Maximus' presentation. This also matches the overall view of continuity Proclus has in each participated structure of reality, as we are about to see.

\section{Proclus' Framework of Participation}

Just as Maximus has an overall three-term scheme for participation, we see this also systematically presented in Proclus. Elements of Theology, ${ }^{15}$ Proposition 23, is one place where that structure is made apparent:

\section{All that is unparticipated gives existence to the participated from itself, and all participated entities reach upwards to unparticipated entities.}

For the unparticipated, having the status of a monad since it belongs to itself and not to another, and since it transcends the participants, generates entities that are able to be participated. For either it will stand barren by itself - and then not have honor-or it will give something from itself. Then that which receives participates, and that which is given has existence as participated. (Dodds 26.2229)

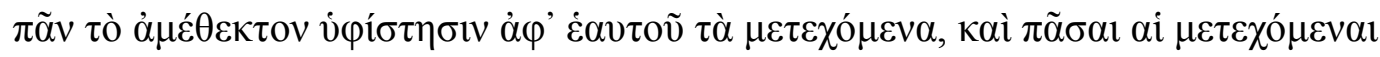

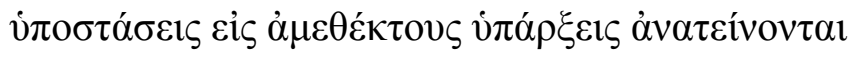

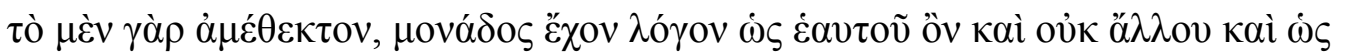

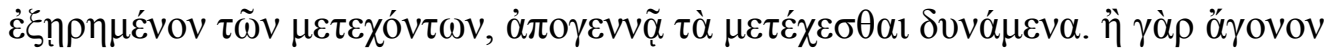

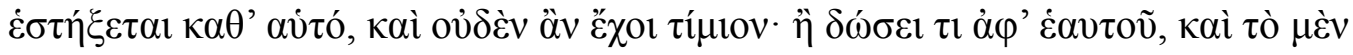

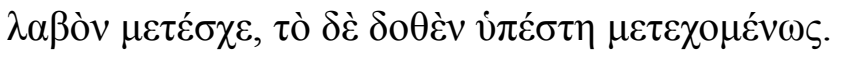

Here, Proclus takes as granted that, for any given number of individuals sharing a property, the source of that property generates entities or principles which proximately impart their common effect in the participants. Whereas a more traditional Platonist framework admits of

\footnotetext{
${ }^{15}$ Here onward abbreviated ' $E T$ '.
} 
two terms - multiple participants correlated to one participated entity or Form-Proclus thinks participation in one source necessitates intermediate, participated principles which each correspond with their respective participants. ${ }^{16}$ For instance, each living body participates in the property of self-movement through its proximate particular soul, while each soul is generated from the monadic, unparticipated principle of Soul. Unparticipated Soul then functions as the source of self-movement for all participants by not being related to any one of them, while a participated soul is the cause of self-motion for its specific participant. Under this description the unparticipated has a one-to-many relationship with the participated and participants, while each participated entity has a one-to-one relationship with the participant. Unparticipated Soul produces multiple, particular souls which act as immediate causes of life to all living bodies, while the individual, participated soul produces its effect in a particular living body.

Within this general three-term structure, Proclus makes an additional distinction: an immanently participated power in the participant, which the separately participated produces as an intermediary between itself and the participant. ${ }^{17}$ From the previous example, each particular soul has a separate, self-complete existence in relation to the living body, while it also generates an immanent power in the body which brings about the manifested effect of life, or self-movement, in the body. As Proclus states in ET Prop. 81: 'All that is separately participated is present to the participant through an unseparated power which it

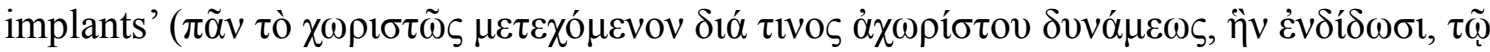

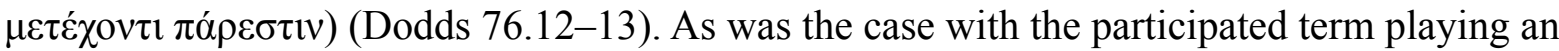
intermediary role between the unparticipated and participants, so also the immanent power functions as an intermediary, making possible the effect of the separately participated in the participant. The structure of participation we now have is then similar to what we saw in Maximus, above: (1) the unparticipated, (2) the participated, as separate from the participant, $\left(2^{*}\right)$ the participated, as an immanent power in the participant, and (3) the participant. One should note that whereas Proclus holds a one-to-many relationship between (1) and (2) (and by proxy with (3)), a one-to-one relationship holds between (2) and ( $\left.2^{*}\right)$ (and again, by proxy with (3)). In this regard the type of mediation differs between (2) and (2*).

\footnotetext{
${ }^{16}$ See Proclus, ET Prop. 23, Dodds 26.30-28.7, quoted below.

17 See ibid. Prop. 64, Dodds 60.20-22: 'Every original monad gives substance to two series: one of self-

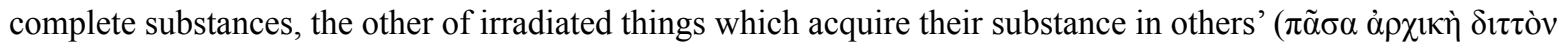

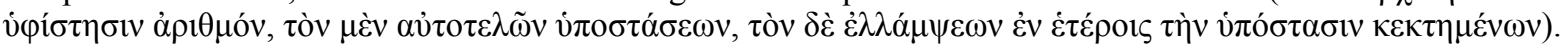


Given this structure, we should see how Proclus justifies the division between the unparticipated and participated — particularly important in comparison to Maximus. The end of ET Prop. 23 gives us a reason with the proof for the unparticipated's priority:

Every participated entity, belonging to that through which it is participated, is secondary to that which is equally present to all and has filled everything from itself. For that which is in one is not in the others; while that which is present to all alike, so that it may illuminate all, is not in one but before all. ... But that which is in all would be divided into all, and again would require another principle to unify the divided; and further all would no longer participate the same principle, but this one and that another, through the unity having been divided. (Dodds 26.30-28.4)

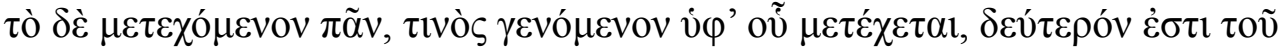

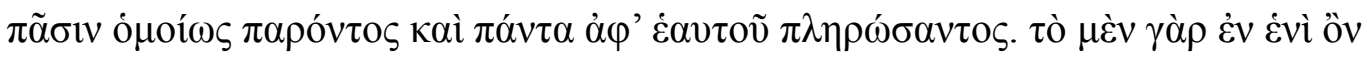

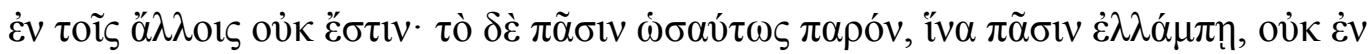

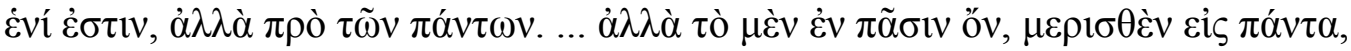

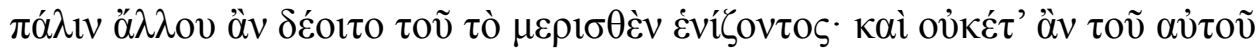

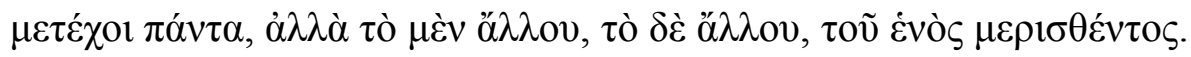

Proclus characterizes each participated entity as being divided and distinct from each other, so that what one individual participates is essentially different from any other participated entity. Going back to the example of souls, Proclus would characterize the differentiation of particular souls according to species. ${ }^{18}$ This would suggest that the soul of Socrates differs from that of Fido according to species, and not just because matter differentiates Socrates and Fido. What unifies all souls together, irregardless of each one's specification for one participant or another, is a principle that is simply 'Soul-itself' and not just 'soul-in-relationto-X'. Consequently 'Soul-itself' would have to be unparticipated in not belonging to specific participants but as being unified before all.

To generalize, the unparticipated functions as the source of a given attribute or principle for all participants by not being differentiated into species or kinds but as being unified with itself as solely the kind, 'soul'. In turn, the participated functions as a bridge by being 'soul' in relation to one participant or another, or as distinguished by species. The unparticipated then grounds the multiple participated entities through its instantiation of a given kind (as with 'soul'), while the differentiation of multiple participated entities makes possible each individual participant possessing a common attribute.

\footnotetext{
18 Proclus specifies this distinction in terms of either species, for non-material entities (like souls), or number for material forms (like the enmattered form of 'man'). See Commentary on Parmenides 819.20-22 (Cousin), 14-16 (Steel); Commentary on Timaeus I 446.24-26.
} 


\section{Comparing Maximus with Proclus}

By comparison to Proclus' systematic framework, the framework in Maximus' CT I.4850 gives us only a rough sketch, but the parallel should already be clear. As we have seen earlier, the same distinction of terms in participation can be seen with (1) the unparticipated, as the source of participants and participated; (2) participated, separately-existing entities; $\left(2^{*}\right)$ immanent powers in the participants, derived from the separately participated; and (3) the participants in themselves. ${ }^{19}$ One difference with (1) is that Maximus does not explicitly refer to God as 'unparticipated', ${ }^{20}$ however the context makes clear that God stands apart from the participated category, especially insofar as he 'infinitely infinite times' transcends both participants and participated entities. ${ }^{21}$ The pre-existence of the participated works before created beings mirrors Proclus' statement that participated entities exist separately and in themselves before their participants. More proximately, this may correspond to Proclus' ET Prop. 63: 'Every unparticipated entity gives existence to two orders of participated beings: one in those which participate at some time, another in those which participate always and by

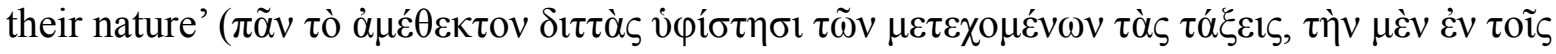

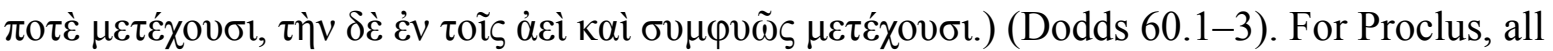
things which temporally participate in some property depend on a prior, eternally existing order of participated principles. To this degree Maximus has a similar idea with the participated works as existing eternally before they can be partaken by temporal beings.

Just as Maximus has two different descriptions of the participated works as either transcending or being immanent in their participants (with (2) and $(2 *)$ ), Proclus also holds that participated entities which exist separately produce an immanent power in their participants which brings about the final effect from the participated entity. Similarly,

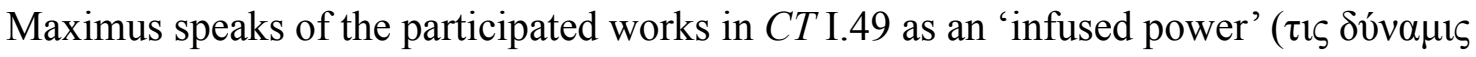
$\check{\varepsilon} \mu \varphi v \tau o \varsigma)$ which manifests that work's characteristic property. The description of 'infused

\footnotetext{
${ }^{19}$ Cf. the distinction for Maximus, p. 6, and for Proclus, p. 8. A small, terminological note: Maximus, Centuries of Theology I.48-50, and the rest of the Centuries generally use only $\mu \dot{\varepsilon} \theta \varepsilon \kappa \tau$ ov to refer to participated entities. Proclus primarily uses $\mu \varepsilon \tau \varepsilon \chi 0$ $\mu \varepsilon v o v$, although in places like ET Prop. 63, Dodds 60.5, he uses the latter interchangeably with the former (Dodds 60.1-2). Otherwise in the case of Prop. 63, neither term appears to differ in meaning from the other.

${ }^{20}$ On doing a word search in Migne's Patrologia Graecae, no mention of $\dot{\alpha} \mu \varepsilon \dot{\varepsilon} \theta \varepsilon \kappa \tau$ ov can be found in the Centuries of Theology or anywhere in the rest of Maximus' corpus.

${ }^{21}$ See also Proclus, ET Prop. 75.
} 
power' also matches Proclus' ET Prop. 81 speaking of the separately participated 'implanting' $(\dot{\varepsilon} \vee \delta i ́ \delta \omega \sigma \iota)$ a non-separate power in the participant. ${ }^{22}$

Given the general parallels, one area of difference can be seen with (2). While Proclus speaks of separately participated entities as having a one-to-one correspondence with their respective participants, Maximus' participated entities have a one-to-many relationship: for instance, multiple created beings having the property of 'goodness' participate in the one participated work of goodness, or 'goodness-itself' ( $\alpha \hat{\tau} \tau \eta \dot{\eta} \dot{\alpha} \gamma \alpha \theta$ ó $\eta \varsigma) .{ }^{23}$ Whereas Proclus would separate a property like 'goodness' into a separate order of participation, with an unparticipated Goodness-itself and separately participated entities corresponding to the number of participants, ${ }^{24}$ Maximus collapses this structure into the participated level (2). In this respect, Maximus differs with Proclus in that a given, separately participated entity can have more than one participant.

This leads to a question about placing God in the role of the unparticipated (1). In Proclus the unparticipated and participated belong to a single kind or order-for instance, unparticipated Soul is one in kind with the participated souls it produces. In Maximus, the participated works eternally produced by God are different in kind and not just one kind-as with goodness, life, being, and so on. At the outset it is not clear how the differing participated works relate to God in kind or order, especially if all relation is denied through God's transcendence. ${ }^{25}$ Yet if we recall I.54 where life and being are equated with 'becoming god', Maximus appears to see both attributes (and perhaps, by implication, the other participated works in I.48-50) as ultimately united in kind with deity. In this sense the Proclean rule of participation belonging to a single order or kind may apply here, if God unites in himself the different attributes that are manifested as participated works. ${ }^{26}$ This

\footnotetext{
${ }^{22}$ Consider also Maximus' distinction between the participated and participating in terms of being either

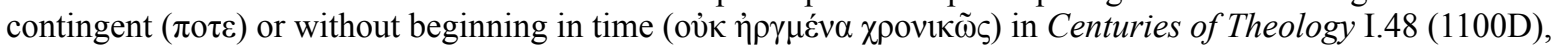
which parallels Proclus' ET Prop. 63 (esp. Dodds 60.4-11), where the unparticipated produces two sets of participated entities: those which are always ( $\dot{\alpha} \varepsilon \dot{)})$ participated, and those which are contingently $(\pi \circ \tau \dot{\varepsilon})$ participated.

${ }^{23}$ See Centuries of Theology I.50, 1101B, where Maximus describes 'all good things and goodness itself; and

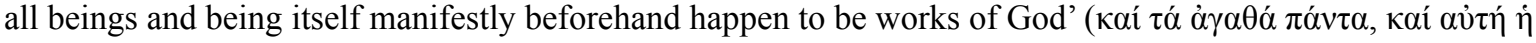

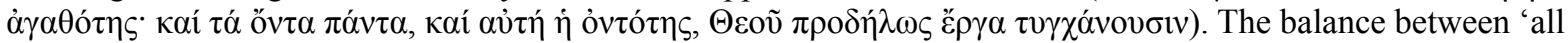
$[\mathrm{X}]$ things and $[\mathrm{X}]$ itself' can be seen to correspond to participated beings with the given property, $\mathrm{X}$, and the participated principle, ' $\mathrm{X}$ ' itself.

${ }^{24}$ This should be distinguished from Proclus' Good-itself qua the One - and in that case Proclus does have an order between the unparticipated One and participated henads, or 'ones'. See, e.g., ET Prop. 21, Dodds 24.2931 , etc.

${ }^{25}$ Cf. p. 4, n. 9.

${ }^{26}$ Maximus the Confessor, CT I.54, 1104B.
} 
would then agree with Proclus' understanding that all things are constituted by unity, where the source of that unity is the One-itself, the Neoplatonic first principle, which is also equated with deity. ${ }^{27}$ The henads, which are participated principles of unity below the One, would then fit analogously with Maximus' participated works. ${ }^{28}$ On the one hand, each henad is entirely 'one' by character, so they collectively have no difference from each other by nature. ${ }^{29}$ Yet insofar as each henad brings about its effect in a specifically different participant (for instance, the henad that is productive of Being is different from that productive of Intellect), each could be said to be differentiated 'aspects' of the One, as the unparticipated source for the common order of henads. ${ }^{30}$ To this degree, Maximus' notion of the participated works as aspects of God would also fit, ${ }^{31}$ insofar as each participated work is a form of participated deity, as seen in I.54.

An additional difference to note for both frameworks is the ontological status of (2). For Proclus, ET Prop. 64's description of the first order of participated entities as 'selfcomplete' ( $\alpha$ $\tau o \tau \varepsilon \lambda \tilde{\omega} v)$ indicates self-subsistence and ontological separation from the participants and the unparticipated source. ${ }^{32}$ As seen earlier, the separate existence of the participated entities makes possible the distribution of a given property in the participants, where Proclus characterizes this pre-existence in terms of the principle's self-subsistence. In Maximus, on the other hand, self-subsistence seems to be denied to the participated works.

\footnotetext{
27 See Proclus, ET Prop. 5. On unity as the proper character of deity, see ET Prop. 113.

${ }^{28}$ I would like to thank Kevin Corrigan for this suggestion, which has also been pointed out in PseudoDionysian studies (e.g. Timothy Riggs, 'Erôs, the Son, and the Gods as Metaphysical Principles in Proclus and Dionysius', Dionysius 28 (2010) 97-130).

${ }^{29}$ See Proclus, Commentary on Parmenides, 1048,14-20, where each henad is absolutely 'all in all' ( $\pi \tilde{\alpha} \sigma \alpha \mathrm{l} \dot{\varepsilon} v$ $\pi \alpha ́ \sigma \alpha ı)$, while each has no common genus with all other henads. Thus only each henad being 'one' is what brings them within the same 'order' ( $\tau \dot{\alpha} \xi 1 \varsigma)$. See also ibid., 745.14-17, where derivation of henads from the One

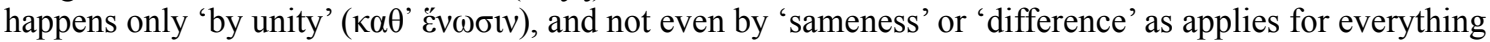
under Being, Intellect, and so on.

${ }^{30}$ One should note that, contrary to certain past interpretations (possibly Laurence Rosán?), the henads should by no means be taken as 'aspects' of the One, as in a proto-monotheistic interpretation. I only use 'aspects' loosely insofar as the henads are derived from the One.

31 Of course, even here the comparison breaks where Proclus speaks of the henads as ineffable and beyond positive description, like the One itself (see Proclus, ET Prop. 115, 118). This would indicate another 'flattening' of horizons under Maximus' framework, where Being-itself and the henad of 'Being' are collapsed in one participated work of 'being', as with Life-itself and the henad of 'Life' into the work of 'life', etc.

32 Dodds 60.31-62.2: 'Accordingly those substances which are self-complete, while by their discrimination into a manifold they fall short of their original monad, are yet in some wise assimilated to it by their self-complete existence; whereas the incomplete not only as existing in another fall away from the monad which exists in itself, but also as incomplete from the all-completing monad' (trans. Dodds, lightly modified) ( $\alpha i \mu \varepsilon \dot{v} v$ oṽv

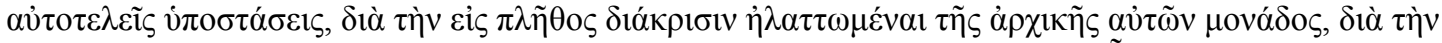

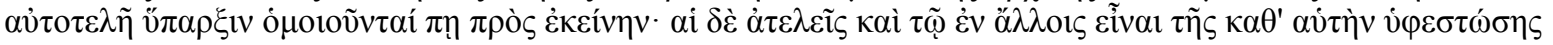

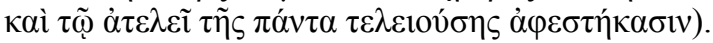


Recalling Maximus' distinction in CT I.48 of works from which God has rested (participating creatures, or (3)) compared to works that God does not rest from (participated works, or (2)), in the previous I.47 Maximus connects God's 'rest' with the resulting work having its own self-determined activity. ${ }^{33}$ By consequence created participants have their own selfdetermined activity, while this is implicitly denied for the participated works since God does not rest from these. As a result, the participated works for Maximus do not appear to have self-subsistence in the way that, for instance, participated souls, and even more so the henads, in Proclus. ${ }^{34}$

\section{Conclusion}

Overall, Maximus' adaptation of Proclus on participation is rather simplified even though the basic structure is in place. Where Proclus employs his framework of participation in positing multiple layers of reality between the first principle, intelligible entities, entities of soul, and material being, Maximus flattens this structure into a straightforward hierarchy between God, the participated, eternal works of God, and creatures in CT I.48-50. This may be why Maximus, unlike Proclus, does not hold that each participated entity belongs to the same kind - that is, being, life, goodness, and so on - except insofar as they share in the common property of divinity, or rather as participated aspects of God. In this, perhaps the crucial difference from Proclus lies in Maximus' denial of self-subsistence to the participated works in their eternal, pre-existing aspect. On the one hand this move blocks calling the participated works separate divinities, as Proclus would with the participated henads.

There is still a lingering difficulty in the ontological status of Maximus' participated entities: they are not self-subsisting, as Proclus' henads, but they are not numerically identical with God (either as parts of an essential definition, or even as essential accidents), so they

\footnotetext{
${ }^{33}$ See $C T$ I.47 1100B-C: 'For God rests from his natural activity in each being by which each of them moves naturally. He rests when each being, having obtained the divine energy in due measure, will determine its own

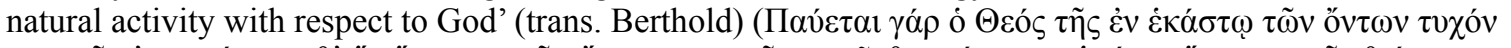

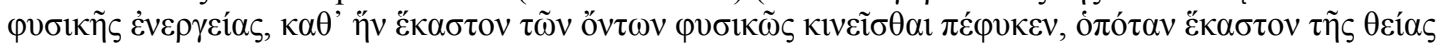

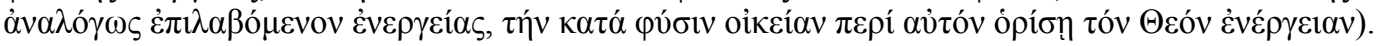

${ }^{34}$ See ET Prop. 114.
} 
appear to be ontologically differentiated. ${ }^{35}$ The ambiguity is one that would continue on to

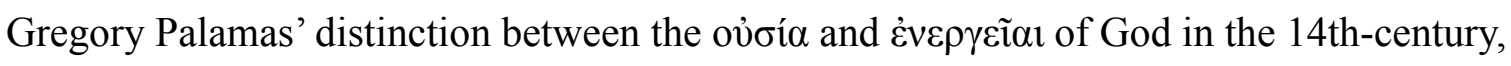
with disputes on how far, or how close, to distinguish the two ontological kinds. In any case, Maximus' affirmation of the participated works as intermediaries fulfills one main criteria from Proclus' framework, where participated entities mediate properties derived from one transcendent source to multiple participants. In Maximus' case with the Centuries of Theology, they fill the conceptual background to explain the language of deification and how things become perfected by God through participation. With this one can see the essential structure of participation from late Neoplatonism still preserved for the Byzantine Christian world with Maximus. ${ }^{36}$

\footnotetext{
${ }^{35}$ For instance, Proclus would say that a thing has subsistence either as a power in its prior cause, as constituting itself as a separate existence, or as immanent in the resulting product (see Proclus, ET Prop. 65). While the middle category of self-subsistence is denied, it is unclear where Maximus might place the participated works-as-pre-existing, particularly if he wishes to maintain the transcendence of God in a way that denies any identity with the participated works. In terms of later developments, D. Bradshaw, Aristotle East and West (2004), 189-90 points out a parallel with Gregory Palamas' distinction between God's essence (ov̉oía) and energies ( $\dot{\varepsilon} v \varepsilon \dot{\varepsilon} \gamma \varepsilon 1 \alpha \mathrm{l})$. Maximus' framework may perhaps lead in this direction, particularly if 'rest' is denied to God's 'works' (๕̌p $\gamma \alpha)$ in their eternal aspect, as seen earlier. If Maximus is taken as a faithful interpreter of Ps.Dionysius in this area, pace S. Gersh, 'Ideas and Energies in Pseudo-Dionysius the Areopagite' (1984) 300, this might constitute a new ontological category for the participated entities, insofar as their ontological status is modified from Proclus while still yet distinct from God in himself.

36 Special thanks to Peter Adamson, Laura Castelli, Kevin Corrigan, Alan Brown, Augustine Casiday, Denis Walter, Daniel Watson, and Dimitrios Vasilakis for their feedback and suggestions for this paper.
} 